\title{
Midtrophic fish feeding modes at the poles: an ecomorphological comparison of polar cod (Boreogadus saida) and Antarctic silverfish (Pleuragramma antarctica)
}

\author{
Erica Carlig ${ }^{1}$ (1) Jørgen S. Christiansen ${ }^{2,3} \cdot$ Davide Di Blasi $^{1} \cdot$ Sara Ferrando $^{4} \cdot$ Eva Pisano $^{1} \cdot$ Marino Vacchi $^{1}$. \\ Richard L. O'Driscoll ${ }^{5}$. Laura Ghigliotti ${ }^{1}$
}

Received: 6 November 2020 / Revised: 22 March 2021 / Accepted: 8 June 2021 / Published online: 20 June 2021

(c) The Author(s) 2021

\begin{abstract}
The polar cod (Boreogadus saida) and the Antarctic silverfish (Pleuragramma antarctica) are pelagic fish endemic to the Arctic and Antarctica sea, respectively. Both species are abundant and play a central role as midtrophic wasp-waist species in polar ecosystems. Due to their biological and ecological characteristics (small size, complex life histories, relatively short generation cycles, movement capability, planktivorous diet, and importance as prey), the polar cod and the Antarctic silverfish are potentially good sentinels of ecosystem change. Changes in polar zooplankton communities are well documented. How changes impact ecosystems as a whole largely depend on the degree of diet specialization and feeding flexibility of midtrophic species. Here, we provide the ecomorphological characterization of polar cod and Antarctic silverfish feeding performances. A comparative functional ecology approach, based on the analysis of morpho-anatomical traits, including calculation of suction index and mechanical advantage in jaw closing, was applied to profile the feeding modes and flexibility of the two species. Ecomorphological evidence supports differences in food acquisition: the polar cod appears able to alternate particulate ram-suction feeding to a pump filter feeding, and the Antarctic silverfish results be both a particulate ram and a tow-net filter feeder. Both species exhibit opportunistic feeding strategies and appear able to switch feeding mode according to the abundance and size of the available prey, which is a clue of potential resilience to a changing environment.
\end{abstract}

Keywords Antarctic silverfish · Polar cod · Ecomorphology · Jaw mechanics · Gill rakers · Feeding strategy

\section{Introduction}

Erica Carlig

ericacarlig@virgilio.it; erica.carlig@ias.cnr.it

1 National Research Council (CNR) of Italy, Institute for the Study of the Anthropic Impacts and the Sustainability of the Marine Environment (IAS), Via De Marini 6, 16149 Genoa, Italy

2 Department of Arctic and Marine Biology, University of Troms $\varnothing$, NO-9037 Troms $\varnothing$, Norway

3 Environmental and Marine Biology, Åbo Akademi University, 20500 Turku, Finland

4 Department of Earth, Environment and Life Sciences (DISTAV), University of Genoa, Corso Europa 26, 16132 Genoa, Italy

5 National Institute of Water and Atmospheric Research Limited, Private Bag 14-901 Kilbirnie, Wellington, New Zealand
Most pelagic ecosystems worldwide, including those of the Polar Regions, rely on a wasp-waist trophic structure. Such a structure is characterized by a few, small-sized, pelagic, planktivorous, and midtrophic species that exert both up and down control of the trophic dynamics (Bakun et al. 2006). These midtrophic species often have complex life histories coupled with relatively short generation cycles, potentially allowing for large fluctuations in population size. Further, they are highly motile, and so potentially able to rapidly change their geographical distribution. Such dynamics in abundance and dispersal have potential to generate dramatic changes in the trophic flow of energy. Due to their ecological role, and sensitivity to change, midtrophic level species are sentinels of the changes of the pelagic ecosystems (Lehodey et al. 2010; Koubbi et al. 2017) and hold potential to provide early warnings on the effects of climate change on the marine ecosystems. 
In polar oceans, only a few midtrophic fishes dominate the pelagic energy flows: the polar cod (Boreogadus saida) in the Arctic and the Antarctic silverfish (Pleuragramma antarctica) in Antarctica are the major plankton feeders linking zooplankton and predators (Christiansen et al. 2012; Vacchi et al. 2012a; Duhamel et al. 2014). Both species are known to primarily feed on copepods, euphausiids, and amphipods (summarized in Table 1), and in turn, they are prey for a suite of predators, from mammals to birds and other fish (Christiansen 2017; Pinkerton 2017).

Polar cod is a gadid species with a circumpolar distribution, mainly at latitudes above the Arctic Circle (Cohen et al. 1990; Mecklenburg et al. 2018). It is abundant in the northern Barents Sea (Ajiad et al. 2011), Svalbard Archipelago (Falk-Petersen et al. 1986; Renaud et al. 2012), Greenland waters (Christiansen et al. 2012), Canadian Arctic Archipelago, Beaufort, and Chuckchi Seas (Crawford et al. 2012). On the Arctic shelves, it dominates in both inshore and offshore waters and throughout the central Arctic Ocean from surface to $~ 1000 \mathrm{~m}$ depth (Geoffroy et al. 2016; Christiansen 2017; Mecklenburg et al. 2018). The polar cod can reach up to $460 \mathrm{~mm}$ in total length (TL) (Mecklenburg et al. 2018), but TL is generally $<250 \mathrm{~mm}$ (Cohen et al. 1990). With an average 7-8 years life span, it becomes sexually mature between the age of 2-3 years (Hop and Gjøsæter 2013; Mueter et al. 2016; Nahrgang et al. 2016) and is the

Table 1 Comparative ecology and life history aspects of the Antarctic silverfish (Pleuragramma antarctica) and the polar cod (Boreogadus saida)

\begin{tabular}{|c|c|c|}
\hline & Pleuragramma antarctica & Boreogadus saida \\
\hline Taxonomy & $\begin{array}{l}\text { Order: Perciformes } \\
\text { Family: Nototheniidae }\end{array}$ & $\begin{array}{l}\text { Order: Gadiformes } \\
\text { Family: Gadidae }\end{array}$ \\
\hline Distribution & Circumpolar-Antarctic & Circumpolar-Arctic \\
\hline & (Map from Duhamel et al. 2014) & (Map from Mecklenburg et al. 2018) \\
\hline Life mode & Pelagic & Pelagic \\
\hline Migration, movements & $\begin{array}{l}\text { Diel vertical migrations with fish moving shallower depths at } \\
\text { night and deeper during the day (Plötz et al. 2001; Fuiman } \\
\text { et al. 2002; Robison 2003; Lancraft et al. 2004) } \\
\text { Spawning migrations are believed to take place from open } \\
\text { waters to the coastal ice shelves (Koubbi et al. 2011; Ghigli- } \\
\text { otti et al. 2017; O'Driscoll et al. 2018) }\end{array}$ & $\begin{array}{l}\text { Adults perform diel vertical migrations under the } \\
\text { ice. Seasonal vertical migrations toward the bot- } \\
\text { tom prior to winter are observed in juveniles and } \\
\text { adults (Benoit et al. 2010; Geoffroy et al. 2016) } \\
\text { The species may undertake extensive migrations } \\
\text { (Ponomarenko 1968; Hop and Gjøsæter 2013; } \\
\text { Kessel et al. 2017) }\end{array}$ \\
\hline Adult size (average) & $15 \mathrm{~cm}$ (Fischer and Hureau 1985) & $25 \mathrm{~cm}$ (Cohen et al. 1990) \\
\hline Maximum age & 14 years (Hubold and Tomo 1989; Sutton and Horn 2011) & 8 years (Gillespie et al. 1997) \\
\hline Trophic level & 3.6-4 (Pinkerton 2017) & 3.3-3.5 (Christiansen et al. 2012) \\
\hline Diet & $\begin{array}{l}\text { Generalist (Pinkerton 2017; Tavernier and Giraldo, 2017) } \\
\text { Opportunistic feeding habit (Pinkerton 2017; Carlig et al. } \\
\text { 2019) } \\
\text { Ontogenic shifts in prey consumption (Kellermann 1987; } \\
\text { Giraldo et al. 2011; Tavernier and Giraldo 2017) } \\
\text { The diet in adults is dominated by euphasiids and copepods; a } \\
\text { number of other invertebrates are taken by adults; piscivory } \\
\text { is uncommon but can be relevant at the local level (Pinkerton } \\
\text { 2017) }\end{array}$ & $\begin{array}{l}\text { Generalist (Walkusz et al. 2013; Gray et al. 2016; } \\
\text { Steiner et al. 2019) } \\
\text { Opportunistic feeding habit (Mueter et al. 2016) } \\
\text { Ontogenic shifts in prey consumption (Matley } \\
\text { et al. 2013; Geoffroy et al. 2016) } \\
\text { The diet in adults is dominated by amphipods, cope- } \\
\text { pods, and young fishes (Matley et al. 2013); appen- } \\
\text { dicularians have occasionally been found to have } \\
\text { relevance at the local level (Nakano et al. 2016) }\end{array}$ \\
\hline
\end{tabular}


most short lived among the codfishes in the Arctic region (Gillespie et al. 1997; Nahrgang et al. 2014). The polar cod life cycle is complex and includes ontogenetic shifts in habitat: eggs develop under the sea ice, and larvae/juveniles remain associated with the sea ice, while sub-adults and adults are found in the water column under the sea ice, in open waters, and also close to the bottom (Christiansen 2017).

Antarctic silverfish is a nototheniid species widely distributed in the shelf waters around the Antarctic continent, including the Scotia Arc and adjacent islands (Gerasimchuk 1986; DeWitt et al. 1990; Knox 1994). Despite its ancestral benthic origin shared with all other notothenioid fishes, this species has evolved an exclusively pelagic life history, with a suite of relevant morphological and physiological adaptations, acquired during the Antarctic notothenioid diversification (DeVries and Eastman 1978; Wöhrmann et al. 1997; Voskoboinikova et al. 2017). The Antarctic silverfish is the only holopelagic notothenioid species (Vacchi et al. 2012b). Its ability to live in the water column has required extensive evolutionary adjustments centered on buoyancy, including deposition of lipids in subcutaneous and intramuscular sacs (Eastman 1988), partial or total reduction of bony elements, and other skeletal trait modifications (Voskoboinikova et al. 2017). Like the polar cod, its life cycle is complex, eggs develop under the fast ice (Vacchi et al. 2012a), larvae and juveniles disperse over the continental shelves (La Mesa et al. 2010), and adults live in the water column (De Witt et al. 1990; Vacchi et al. 2012b) from surface to $900 \mathrm{~m}$ depth (Gerasimchuk 1986; DeWitt et al. 1990; Knox 1994; Fuiman et al. 2002). The Antarctic silverfish may attain a maximum TL of $245 \mathrm{~mm}$ (Hubold and Tomo 1989), but TL is generally around $150 \mathrm{~mm}$ (Fischer and Hureau 1985). A relatively slow growth and long life were reported for this species that becomes sexually mature between the age of 4-7 years ( $\mathrm{La}$ Mesa and Eastmann 2012) and lives up to 14 years (Hubold and Tomo 1989; Sutton and Horn 2011).

Although phylogenetically and geographically distant, the polar cod and Antarctic silverfish have been subjected to similar ecological drivers during their independent evolutionary histories in the Polar Regions. They show comparable biological and ecological adaptations, and currently occupy a similar position in their respective food webs. Their abundance and distribution affect the food-web structure, and any fluctuation of those parameters might lead to alternative pathways of energy flow, with repercussions for the whole ecosystem (Bradstreet et al. 1986; Murphy et al. 2016; Aune et al. 2021).

For both the Southern Ocean and Arctic waters, alterations in the physical environment drive the distribution of species, including those of the zooplankton community, leading to change in densities, size, and energetic value of the potential prey of midtrophic level fishes (Brodeur et al.
1999; Beaugrand et al. 2003; Mintenbeck et al. 2012; Henson et al. 2016; Mintenbeck and Torres 2017; Rogers et al. 2020). Such alterations might lead to changes in the distribution and abundance of midtrophic species, as well as on their body condition and energetic value for the upper trophic level, in which extent and relevance largely depend upon each species' degree of diet specialization and feeding flexibility.

Three broad methods of prey capture are known in fishes: suction feeding, ram feeding, and manipulation (Liem 1980). In suction feeding, the predator expands the buccal cavity creating a pressure gradient that forces the prey to move towards the mouth opening. In ram feeding, the predator ingests free-swimming prey by forward movement of the body and protruding jaws. Manipulation is a less common method, where the jaws are directly applied to the prey and used to remove it from the substratum (Wainwright and Bellwood 2002). Pure suction and pure ram feeding are relatively rare, the combination of both modes seems to be the most used. Suction and ram feeding represent ends of a continuum with in which many species fall, and in most of cases, the appropriate definition of their feeding mode would rather be ram-suction feeding (Norton and Brainerd 1993). Two distinct feeding modes are typical of planktivorous species, such as the species considered herein, particulate feeding, and filter feeding (reviewed in Lazzaro 1987). Particulate feeders attack single individual planktonic prey which they visually select from the water column. By contrast, filter feeders do not visually detect individual prey and engulf a volume of water containing the planktonic prey which are retained by entrapment structures, such as gill rakers. Furthermore, filter feeding may be sub-divided into two modes: the tow-net filter feeders which surround the prey with their open mouths while swimming rapidly and the pump filter feeders which use rhythmic suctions to capture prey while swimming slowly (Lazzaro 1987).

The feeding ability and flexibility of fish are largely determined by the functional morphology of the feeding apparatus (Wainwright 1988; Sonnefeld et al. 2014; Gidmark et al. 2019). The anatomical and mechanical features of the muscle-skeleton systems involved in the feeding activities determine how fishes detect, pursue, capture, and successfully handle the prey (Wainwright 1988) and, ultimately, provide insights into the ecological roles of species (Motta et al. 1995; Westneat 2006).

The suction index (SI) and the jaw-closing mechanical advantage (MA) are often used to infer the feeding strategies of fish (Wainwright and Bellwood 2002; Gidmark et al. 2019).

The SI evaluates the suction feeding capability based on transmission of muscular force to the buccal cavity (Collar and Wainright 2006). High SI values imply capability of rapid movements of the jaws, whereas a low SI indicates 
slow movements of the jaws (Bansode et al. 2014). The MA, on the other hand, is the capability to produce force with jaws, and it is inversely proportional to the speed of the lower jaw movements (Westneat 2006). A low MA indicates great velocity transfer and typifies species with weak, rapidly closing jaws. A high MA is typical of species with great force transmission due to strong, slowly closing jaws (Bansode et al. 2014). As such, SI and MA measures can be used to infer the mechanism by which the fish uses jaws to catch the prey, i.e. the main feeding mode.

Considerable advances in our understanding of the mechanical basis of feeding performance in fishes have been made with the increase of ecomorphological studies offering insights on diversified ecological roles of the species by highlighting their potential prey usage, providing information on their feeding flexibility, and investigating their capability to adapt to changes in the prey availability (Wainwright and Bellwood 2002; Barnett et al. 2006). However, despite its high potential value, the actual role of the head and jaw morphology in shaping food habits of fishes living in polar environments is poorly known (Klingenberg and Ekau 1996; Bansode et al. 2014). A morphometric analysis of the feeding structures and biomechanics of three Antarctic notothenioids, including the Antarctic silverfish, was recently performed leading to a better definition of their degree of feeding specialization (Carlig et al. 2018).

Here, the feeding performance and potential for resource usage of the polar cod and the Antarctic silverfish were evaluated through an ecomorphological analysis. Key morphological traits of the head and jaw regions were measured to estimate the suction index (SI) and the mechanical advantage (MA). Since gill raker morphology is known to play an important role in food particle retention in planktivorous fishes (Gerking 1994; Tanaka et al. 2006), such structures were also considered.

The foraging flexibility of the polar cod and the Antarctic silverfish, as inferred from the ecomorphological analyses, is compared and discussed in context of ongoing climate

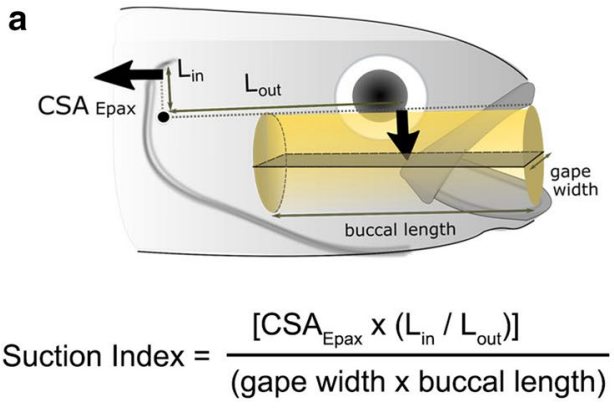

Fig. 1 a Scheme of the traits and levers involved in the mechanism of rotation of the neurocranium for the mouth opening to create the pressure gradient of the suction index ( modified from Carroll and change. This information is particularly relevant because it provides clues about how species modify the feeding mode in response to change in environment and prey availability.

\section{Materials and methods}

\section{Sampling}

Polar cod Boreogadus saida $(n=15)$ were sampled in September 2017 during the TUNU-VII Expedition as part of the international TUNU-Programme (Christiansen 2012). Fish were collected from the RV Helmer Hanssen by bottom trawl at a depth of $392 \mathrm{~m}$ in Isfjorden (Spitsbergen), frozen, and preserved at $-20^{\circ} \mathrm{C}$ for later analyses.

Antarctic silverfish Pleuragramma antarctica $(n=15)$ were caught in February 2015 during a New Zealand survey onboard of the RV Tangaroa. Specimens were collected by midwater trawl at a depth of $540 \mathrm{~m}$ (O'Driscoll and Double 2015).

In order to minimize bias in this study, at the intra-specific level related to ontogeny, only adult specimens were analysed. To compare individuals and species of different total length, morphological measurements were standardized to the standard length of each individual (Barnett et al. 2006).

Species were of similar body size and standard lengths (SL) ranged: B. saida $114-166 \mathrm{~mm} ;$ P. antarctica 151-198 mm, attributable to adult body sizes for both species (Cohen et al. 1990; La Mesa and Eastmann 2012).

\section{Ecomorphological analyses}

Calculations of morphological metrics of mouth structures and muscles of the head were conducted after dissecting the connection between muscles and bones. Measures were taken in $\mathrm{mm}$ to the nearest $0.01 \mathrm{~mm}$.

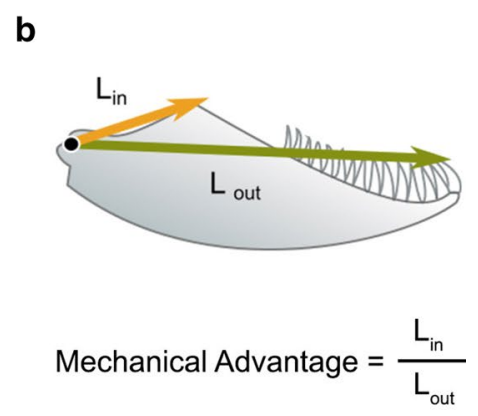

Wainwright 2006). b Lower jaw-closing lever mechanism for the calculation of the mechanical advantage (modified from Wainwright and Bellwood 2002) 
The relationship between mouth morphology and suction feeding performance was estimated by the Suction Index (SI) (Collar and Wainwright 2006; Bansode et al. 2014). The model for SI (Fig. 1a) is based on the transmission of force from the epaxialis muscle to the buccal cavity, generating negative pressure that allows the predator to engulf its prey.

Following Carroll et al. (2004), SI was calculated as follows:

$S I=\frac{\left[\operatorname{CSA}_{\text {epax }}\left(\frac{L_{\text {in }}}{L_{\text {out }}}\right)\right]}{\text { (gape width } \times \text { buccal length) }}$

where CSA $_{\text {epax }}$ is the cross-sectional area of the epaxialis, $L_{\text {in }}$ is the moment arm of the epaxialis, and $L_{\text {out }}$ is the moment arm of the buccal cavity. The cross-sectional areas of the ellipse-shaped epaxialis were calculated by the measurements of their axes. The major axis was measured from the supracleithrum-posttemporal (S-PT) joint to the dorsal margin of the epaxialis; the minor as the lateral width of the epaxialis. The $L_{\text {in }}\left(L_{\text {in }} \mathrm{SI}\right)$ was calculated as the vertical distance between the centroid of the epaxialis muscles' cross section and the S-PT, and $L_{\text {out }}\left(L_{\text {out }} \mathrm{SI}\right)$ was measured from the S-PT joint to the middle of the buccal cavity (see Collar and Wainwright 2006). Gape width (measured as the distance between the left and right coronoid processes of the mandible) and buccal length (measured as the distance between the anterior tip of the mandible and the depression in the sternohyoideus) were calculated to estimate the volume of the buccal cavity.

The capability of the fish to produce force during the closing of the lower jaw was evaluated from the Mechanical Advantage (MA) in jaw closing (Fig. 1b). We measured the lever arms associated with jaw-closing systems (Bansode et al. 2014). The MA was calculated as the ratio of the jaw closing in-lever $\left(L_{\text {in }} \mathrm{MA}\right)$ to the jaw-closing outlever $\left(L_{\text {out }} \mathrm{MA}\right) . L_{\text {in }} \mathrm{MA}$ was measured as the distance from the quadrate-articular joint to the point of insertion of the adductor mandibulae muscle on the lower jaw, $L_{\text {out }} \mathrm{MA}$ as the distance from the quadrate-articular joint to the anterior-most tooth of the lower jaw (Westneat 2004; Bansode et al. 2014).

For the gill raker morphological analysis, the first left branchial arch was cut off from the gill. The gill arches were mounted with the gill rakers perpendicular to the base of the arch (Amundsen et al. 2004) and were observed under an Olympus SZX7 stereo microscope. Gill rakers were photographed by a Nikon "DS-L3" digital camera mounted on the microscope, and measurements taken to the nearest $0.01 \mathrm{~mm}$. For each specimen, the length of the gill arch (LA) was measured, and the number of the gill rakers $(\mathrm{NG})$ were counted; the length of gill rakers (LG), the spacing between subsequent gill rakers (SG), and the width of gill rakers
(WG) were measured for five gill rakers from the midsection of the gill arch (Tanaka et al. 2006). The filtering area, i.e. by approximating the set of gill rakers and gill arch as a rectangle (Magnuson and Heitz 1971), was calculated as the product of LG and LA.

\section{Statistical analyses}

The suction index (SI), the mechanical advantage (MA), and the surface area of gill rakers (standardized by $\mathrm{SL}^{2}$ ) for polar cod vs. Antarctic silverfish were tested. Data were transformed in $\arcsin \sqrt{p}$. After testing normality and homoscedasticity of the distributions with Shapiro-Wink and Levene tests, $t$ tests were conducted for each variable. Statistical significance was determined at $\alpha=0.05$.

To investigate which morphometric features explain the greatest variations between the two polar species, a principal component analysis (PCA) involving 13 morphological traits was developed. The variables considered were the morphological traits used for the SI and MA metrics, the lengths of the head and mouth, and gill rakers and gill arch metrics. The morphological measurements were standardized relative to the body size (SL) of each individual (Barnett et al. 2006). The 13 morphological traits were compared with $t$ tests. The non-parametric Wilcoxon test was used when the assumptions of normality and homogeneity of variance of the data were not respected.

Statistical analyses were performed using the software $\mathrm{R}$ 3.2.2 (R Development Core Team 2015).

\section{Results}

The SI mean value was higher in polar cod than in Antarctic silverfish $(0.070 \pm 0.014 \mathrm{SD}$ and $0.060 \pm 0.011 \mathrm{SD}$, respectively; Fig. 2a). Conversely, the mean MA index was higher in Antarctic silverfish than in polar cod $(0.253 \pm 0.019 \mathrm{SD}$ and $0.223 \pm 0.025 \mathrm{SD}$, respectively; Fig. 2b). Both SI and MA significantly differed between the two species $(t=2.22$; $p=0.0351$ and $t=-2.96 ; p=0.0066$, respectively).

The filtering surface was significantly larger for polar $\operatorname{cod}(0.0060 \pm 0.0006 \mathrm{SD})$ compared to Antarctic silverfish $(0.0047 \pm 0.0006 \mathrm{SD} ; t$ test, $t=5.75, p<0.0001 ;$ Fig. $2 \mathrm{c})$.

The head length and buccal length of Antarctic silverfish were significantly longer than those of polar cod, but polar cod had a larger gape width (Table 2). When calculating the suction index (SI) and the mechanical advantage (MA), significant differences were detected between $L_{\text {out }} \mathrm{SI}$ and $L_{\text {out }} \mathrm{MA}$. All the measures of gill rakers were significantly different between the two species (Table 2). Polar cod had longer and more numerous gill rakers than Antarctic silverfish. In Antarctic silverfish, the gills arches were significantly longer and the gill rakers resulted more spaced and 

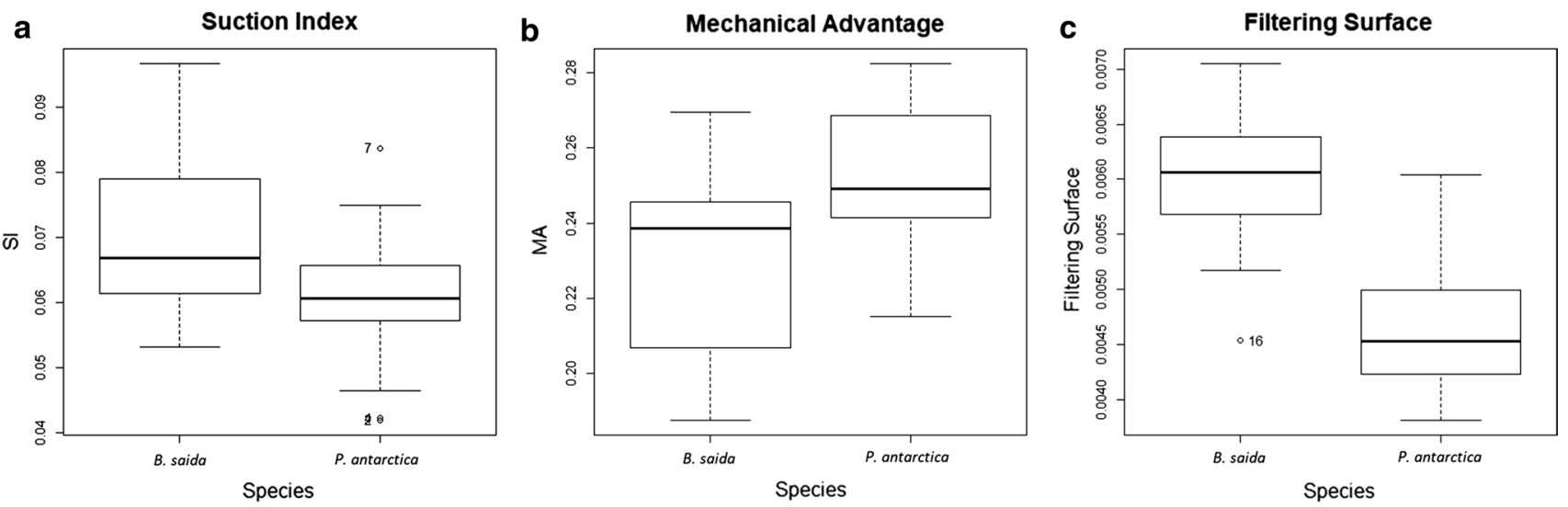

Fig. 2 Boxplots of the values of a suction index (SI), b mechanical advantage (MA), and $\mathbf{c}$ filtering surface calculated on the two polar species

Table 2 Mean values and standard deviation of the 13 morphological traits. Measures were standardized by SL

\begin{tabular}{lccc}
\hline Trait & $\begin{array}{l}\text { Boreogadus saida } \\
(\mathrm{n}=15) \text { mean } \pm \mathrm{SD}\end{array}$ & $\begin{array}{l}\text { Pleuragramma antarc- } \\
\text { tica }(\mathrm{n}=15) \text { mean } \pm \mathrm{SD}\end{array}$ & P value \\
\hline Head length (HL) & $0.2351 \pm 0.0065$ & $0.2740 \pm 0.0087$ & $p<0.0001$ \\
Gape width (GW) & $0.0773 \pm 0.0032$ & $0.0679 \pm 0.0044$ & $p<0.0001$ \\
Buccal length (BL) & $0.0941 \pm 0.0134$ & $0.1453 \pm 0.0063$ & $p<0.0001^{*}$ \\
Cross-sectional area $\left(\mathrm{CSA}_{\text {epaxialis }}\right)$ & $0.0538 \pm 0.0040$ & $0.0550 \pm 0.0028$ & $p=0.3518$ \\
In-lever suction Index $\left(\mathrm{L}_{\text {in }} \mathrm{SI}\right)$ & $0.0200 \pm 0.0020$ & $0.0213 \pm 0.0016$ & $p=0.0674$ \\
Out-lever suction Index $\left(\mathrm{L}_{\text {out }} \mathrm{SI}\right)$ & $0.1154 \pm 0.0061$ & $0.1099 \pm 0.0037$ & $p=0.0069$ \\
In-lever mechanical advantage $\left(\mathrm{L}_{\text {in }} \mathrm{MA}\right)$ & $0.0307 \pm 0.0034$ & $0.0347 \pm 0.0028$ & $p=0.0017$ \\
Out-lever mechanical advantage $\left(\mathrm{L}_{\text {out }} \mathrm{MA}\right)$ & $0.1339 \pm 0.0048$ & $0.1369 \pm 0.0052$ & $p=0.1136$ \\
Gill raker length (LG) & $0.0322 \pm 0.0027$ & $0.0235 \pm 0.0025$ & $p<0.0001$ \\
Gill raker spacing (SG) & $0.0031 \pm 0.0002$ & $0.0034 \pm 0.0004$ & $p=0.0391$ \\
Gill raker width (WG) & $0.0020 \pm 0.0002$ & $0.0029 \pm 0.0002$ & $p<0.0001$ \\
Gill arch length $(\mathrm{LA})$ & $0.1861 \pm 0.0124$ & $0.1980 \pm 0.0119$ & $p=0.0125$ \\
Gill raker number $(\mathrm{NG})$ & $40.07 \pm 2.91$ & $27.67 \pm 2.92$ & $p<0.0001$ \\
\hline
\end{tabular}

*Wilcoxon test thicker (Fig. 3; Table 2). According to the PCA, 75.64\% of the variance was explained on the first three axes (Table 3). The two species appear well distinct along the PC1 axis, which ordination is driven by head and buccal length, which are directly involved both in MA and SI, and by features of the filtration system of the gill rakers (Fig. 4).

\section{Discussion}

Following a functional ecology approach (sensu Villéger et al. 2017) to better understand the ecological processes that operate in nature (McGill et al. 2006; Luiz et al. 2019), we profiled the food acquisition of the polar cod and the Antarctic silverfish from key morpho-anatomical traits, and calculation of jaw-closing force transmission (MA) and suction index (SI).

The biomechanics of feeding in the two species resulted differed significantly, with the polar cod having lower MA and higher SI than the Antarctic silverfish (Fig. 2a, b). In the frame of the available information on fish species, and based on the classification of suction feeders below 0.23 MA and biters above 0.27 MA (Wainwright and Richard 1995), this places the polar cod at the upper end of the MA range of suction feeders, while the Antarctic silverfish lies in between the suction feeders and the biters (Table 4).

Datasets from literature about jaw closing in polar and non-polar fishes show a wide range of MA values (Table 4). A high MA value defines fishes that are manipulators, i.e. species that bite or crush hard body prey, e.g. crustaceans or bivalves. The blue-striped grunt (Haemulon sciurus), 


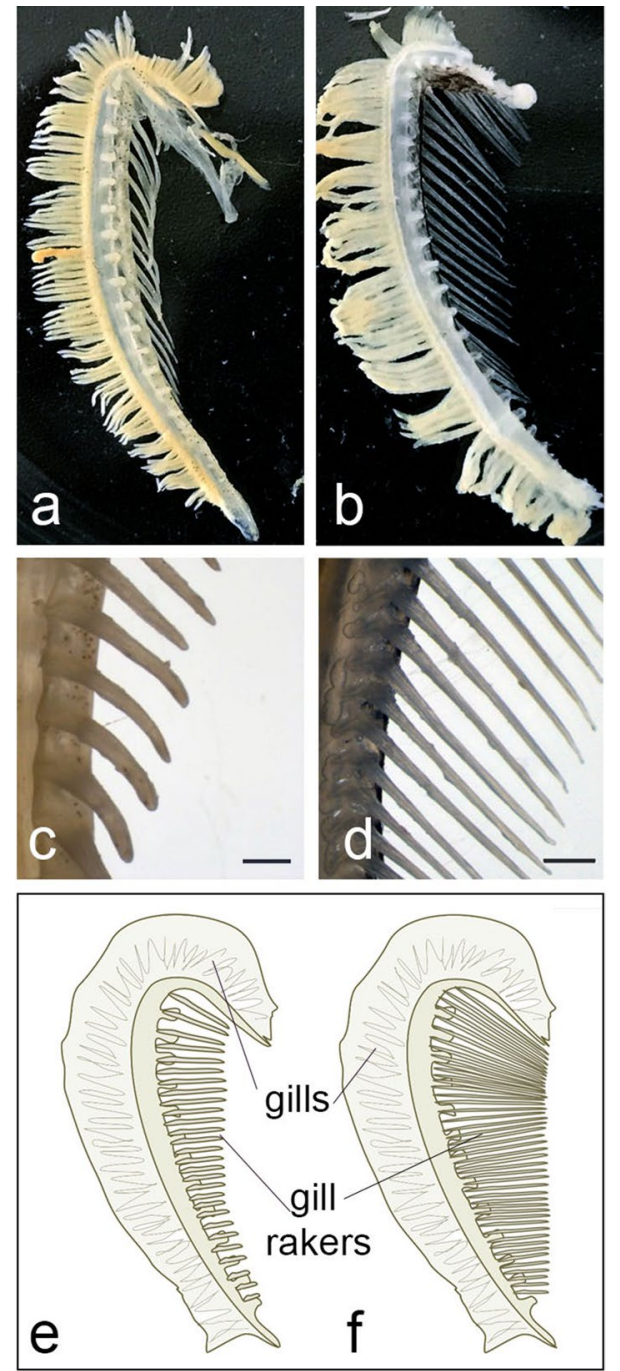

Fig. 3 Gill arch morphology of Pleuragramma antarctica (a, e) and Boreogadus saida $(\mathbf{b}, \mathbf{f})$. Detail of gill rakers of Pleuragramma antarctica (c) and Boreogadus saida (d). Scale bar $1 \mathrm{~mm}$

feeding exclusively on benthic prey as brachyuran crabs and polychaetes, is an example of this group. The feeding performance of the blue-striped grunt is optimized by the presence of robust oral jaws, small gape, high MA of jaw closing, and powerful force-generating capability of the adductor mandibulae (Liem 1980; Wainwright and Bellwood 2002). The highest MA value is found in species which feeds on epilithic and endolithic autotrophic microorganisms, like the scarrid daisy parrotfish (Chlorurus sordidus) that crops, scrapes, or bites the calcareous substrate of the coral reef surface with their beak-like and extremely powerful jaws (Lange et al. 2020). For the large pelagic fishes, such as Atlantic Spanish mackerel (Scomberomorus maculatus), greater amberjack (Seriola dumerili) and common dolphinfish (Coryphaena hippurus), high MA values relate to ram feeding as the capability to produce force with jaws allows
Table 3 Coefficients of the 13 traits selected to describe differences in the feeding apparatus of Boreogadus saida and Pleuragramma antarctica as resulting from the PCA after standardization by SL

\begin{tabular}{|c|c|c|c|}
\hline & $\mathrm{PC} 1$ & PC2 & PC3 \\
\hline Variance & 6.167 & 2.454 & 1.213 \\
\hline$\%$ of variance & 47.417 & 18.877 & 9.331 \\
\hline Cumulative $\%$ of variance & 47.440 & 66.313 & 75.644 \\
\hline \multicolumn{4}{|l|}{ Traits } \\
\hline Head length (HL) & 0.948 & -0.039 & 0.115 \\
\hline Gape width (GW) & -0.767 & -0.138 & 0.225 \\
\hline Buccal length (BL) & 0.931 & -0.257 & 0.036 \\
\hline Cross-sectional area $\left(\mathrm{CSA}_{\text {epaxialis }}\right)$ & 0.143 & -0.864 & 0.408 \\
\hline In-lever suction index $\left(\mathrm{L}_{\mathrm{in}} \mathrm{SI}\right)$ & 0.317 & -0.841 & 0.374 \\
\hline Out-lever suction index $\left(\mathrm{L}_{\text {out }} \mathrm{SI}\right)$ & -0.463 & 0.421 & 0.496 \\
\hline $\begin{array}{l}\text { In-lever mechanical advantage } \\
\left(\mathrm{L}_{\text {in }} \mathrm{MA}\right)\end{array}$ & 0.671 & 0.266 & -0.119 \\
\hline $\begin{array}{l}\text { Out-lever mechanical advantage } \\
\left(\mathrm{L}_{\text {out }} \mathrm{MA}\right)\end{array}$ & 0.384 & 0.591 & 0.492 \\
\hline Gill raker length (LG) & -0.879 & -0.103 & 0.218 \\
\hline Gill raker spacing (SG) & 0.487 & -0.369 & -0.025 \\
\hline Gill raker width (WG) & 0.937 & 0.148 & 0.092 \\
\hline Gill arch length (LA) & 0.427 & 0.385 & 0.513 \\
\hline Gill raker number (NG) & -0.900 & 0.013 & 0.141 \\
\hline
\end{tabular}

In each component, highest and lowest (relative of driving variables) coefficients are in bold

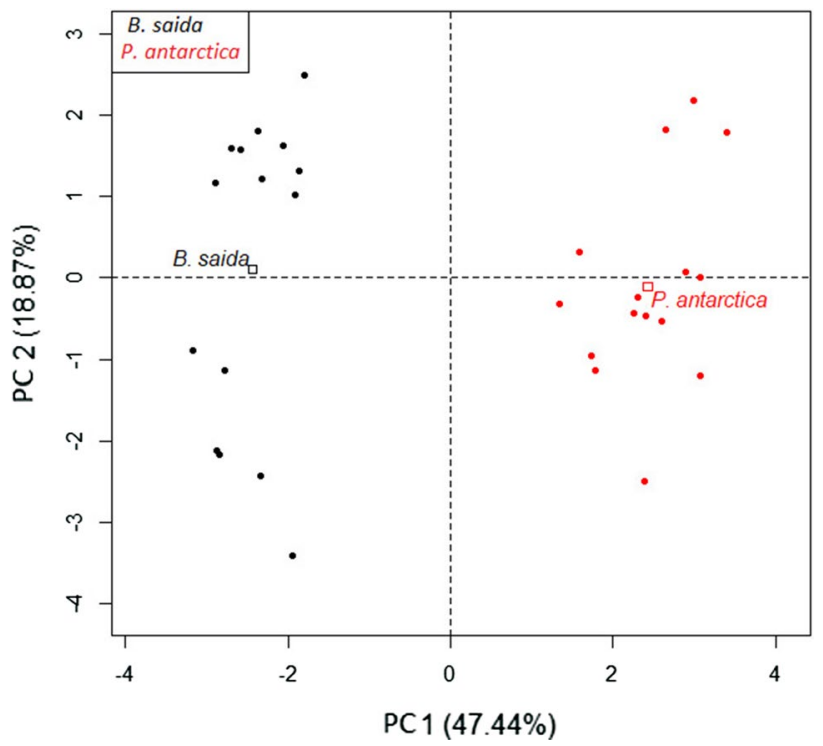

Fig. 4 Principal component analysis plot developed on 13 morphological traits of feeding apparatus of Boreogadus saida and Pleuragramma antarctica

to grab nekton such as fishes and large pelagic invertebrates (e.g. squid) during rapid swimming. In the case of the grey snapper (Lutjanus griseus), with varied diet, a high MA 
Table 4 Mean SI and MA values of the Antarctic silverfish (Pleuragramma antarctica) and polar cod (Boreogadus saida) are compared to the values found in literature for other fish species

\begin{tabular}{|c|c|c|c|c|c|}
\hline Species & Family & Max length & Habitat & Food habits & SI \\
\hline Opsanus tau & Batrachoididae & $43.2 \mathrm{~cm}$ TL [1] & Demersal & BI [2] & 0.02 \\
\hline Dissostichus mawsoni & Nototheniidae & $200 \mathrm{~cm}$ TL [3] & Demersal & F; NI [4] & 0.03 \\
\hline Scomberomorus maculatus & Scombridae & $91 \mathrm{~cm} \mathrm{FL} \mathrm{[5]}$ & Pelagic & F; NI [6] & 0.04 \\
\hline Micropterus salmoides & Centrarchidae & $97 \mathrm{~cm} \mathrm{TL} \mathrm{[7]}$ & Demersal & F; BI; V [7] & 0.05 \\
\hline Coryphaena hippurus & Coryphaenidae & $210 \mathrm{~cm}$ TL [8] & Pelagic & F; NI [9] & 0.06 \\
\hline Pleuragramma antarctica & Nototheniidae & $25 \mathrm{~cm}$ TL [10] & Pelagic & $\mathrm{MZ} ; \mathrm{Z}[11]$ & 0.06 \\
\hline Epinephelus drummonhayi & Serranidae & $110 \mathrm{~cm}$ TL [12] & Demersal & $\mathrm{BI} ; \mathrm{F}[2]$ & 0.06 \\
\hline Boreogadus saida & Gadidae & $30 \mathrm{~cm}$ TL [13] & Pelagic & MZ; Z; F; BI [14] & 0.07 \\
\hline Ambloplites ariommus & Centrarchidae & $30.5 \mathrm{~cm}$ TL [1] & Demersal & F; BI; NI [7] & 0.07 \\
\hline Seriola dumerili & Carangidae & $190 \mathrm{~cm}$ TL [15] & Pelagic & $\mathrm{F} ; \mathrm{NI}[15]$ & 0.08 \\
\hline Lutjanus griseus & Lutjanidae & $89 \mathrm{~cm}$ TL[16] & Demersal & F; BI; NI; MZ[17] & 0.12 \\
\hline Haemulon sciurus & Haemulidae & $46 \mathrm{~cm}$ TL [18] & Demersal & $\mathrm{BI} ; \mathrm{F}[18]$ & 0.16 \\
\hline Enneacanthus obesus & Centrarchidae & $9.5 \mathrm{~cm}$ TL [7] & Demersal & BI; NI [7] & 0.22 \\
\hline Lepomis punctatus & Centrarchidae & $20 \mathrm{~cm} \mathrm{TL}$ [7] & Demersal & BI; NI; MZ; Z [7] & 0.22 \\
\hline Lycodichthys dearboni & Zoarcidae & $23 \mathrm{~cm}$ TL [19] & Demersal & MZ; BI [19] & 0.23 \\
\hline Trematomus bernacchii & Nototheniidae & $28 \mathrm{~cm}$ TL [10] & Demersal & MZ; BI; F [20] & 0.27 \\
\hline Pagrus pagrus & Sparidae & $91 \mathrm{~cm} \mathrm{TL} \mathrm{[1]}$ & Demersal & $\mathrm{BI} ; \mathrm{F}[21]$ & 0.28 \\
\hline Lepomis gibbosus & Centrarchidae & $40 \mathrm{~cm}$ TL [7] & Demersal & F; V[7] & 0.33 \\
\hline Lepomis macrochirus & Centrarchidae & $41 \mathrm{~cm} \mathrm{TL} \mathrm{[7]}$ & Demersal & BI;F; NI [7] & 0.40 \\
\hline Species & Family & Max length & Habitat & Food habits & MA \\
\hline Hiodon alosoides & Hiodontidae & $52 \mathrm{~cm}$ FL[1] & Pelagic & $\mathrm{BI}$; NI; F; V[22] & 0.12 \\
\hline Clepticus parrae & Labridae & $30 \mathrm{~cm}$ TL [23] & Demersal & MZ; Z [17] & 0.19 \\
\hline Atherinomorus lacunosus & Atherinidae & $25 \mathrm{~cm}$ TL [24] & Pelagic & $\mathrm{Z}[24]$ & 0.21 \\
\hline Elops saurus & Elopidae & $100 \mathrm{~cm} \mathrm{TL} \mathrm{[23]}$ & Pelagic & NI; F [25] & 0.21 \\
\hline Boreogadus saida & Gadidae & $30 \mathrm{~cm}$ TL [13] & Pelagic & MZ; Z; F; BI [14] & 0.22 \\
\hline Halichoeres pictus & Labridae & $13 \mathrm{~cm} \mathrm{TL} \mathrm{[23]}$ & Demersal & $\mathrm{BI} ; \mathrm{MZ}$ [23] & 0.23 \\
\hline Oncorhynchus tshawytscha & Salmonidae & $150 \mathrm{~cm}$ TL [26] & Demersal & BI; F; NI [26] & 0.23 \\
\hline Pleuragramma antarctica & Nototheniidae & $25 \mathrm{~cm} \mathrm{TL} \mathrm{[10]}$ & Pelagic & $\mathrm{MZ} ; \mathrm{Z}[11]$ & 0.25 \\
\hline Micropterus salmoides & Centrarchidae & $97 \mathrm{~cm} \mathrm{TL}$ [7] & Demersal & F; BI; V [7] & 0.25 \\
\hline Gadus morhua & Gadidae & $200 \mathrm{~cm}$ TL [14] & Demersal & BI; F [14] & 0.25 \\
\hline Lycodichthys dearboni & Zoarcidae & $23 \mathrm{~cm} \mathrm{TL} \mathrm{[19]}$ & Demersal & MZ; BI [19] & 0.25 \\
\hline Opsanus tau & Batrachoididae & $43.2 \mathrm{~cm} \mathrm{TL} \mathrm{[1]}$ & Demersal & $\mathrm{BI}[2]$ & 0.25 \\
\hline Scomber scombrus & Scombridae & $60 \mathrm{~cm}$ FL [5] & Pelagic & $\mathrm{MZ} ; \mathrm{Z} ; \mathrm{F}[27]$ & 0.27 \\
\hline Dissostichus mawsoni & Nototheniidae & $200 \mathrm{~cm} \mathrm{TL} \mathrm{[3]}$ & Demersal & F; NI[4] & 0.28 \\
\hline Trematomus bernacchii & Nototheniidae & $28 \mathrm{~cm} \mathrm{TL}[10]$ & Demersal & MZ; BI; F [20] & 0.28 \\
\hline Sardinella aurita & Clupeidae & $41 \mathrm{~cm}$ TL [28] & Pelagic & $Z[28]$ & 0.31 \\
\hline Pagrus pagrus & Sparidae & $91 \mathrm{~cm} \mathrm{TL}[1]$ & Demersal & $\mathrm{BI} ; \mathrm{F}[21]$ & 0.36 \\
\hline Haemulon sciurus & Haemulidae & $46 \mathrm{~cm} \mathrm{TL} \mathrm{[18]}$ & Demersal & BI; F [18] & 0.47 \\
\hline Lutjanus griseus & Lutjanidae & $89 \mathrm{~cm} \mathrm{TL}[16]$ & Demersal & F; BI; NI;MZ [17] & 0.50 \\
\hline Scomberomorus maculatus & Scombridae & $91 \mathrm{~cm}$ FL [5] & Pelagic & F; NI [6] & 0.51 \\
\hline Coryphaena hippurus & Coryphaenidae & $210 \mathrm{~cm} \mathrm{TL} \mathrm{[8]}$ & Pelagic & F;NI [9] & 0.56 \\
\hline Epinephelus drummonhayi & Serranidae & $110 \mathrm{~cm}$ TL [12] & Demersal & $\mathrm{BI} ; \mathrm{F}[2]$ & 0.56 \\
\hline Seriola dumerili & Carangidae & $190 \mathrm{~cm} \mathrm{TL} \mathrm{[15]}$ & Pelagic & F; NI [15] & 0.62 \\
\hline Chlorurus sordidus & Scaridae & $40 \mathrm{~cm}$ TL [29] & Demersal & A [29] & 0.68 \\
\hline
\end{tabular}

Fishes (F); Nectonic invertebrates (NI); Benthic invertebrates (BI); Zooplankton (Z); Macrozooplancton (MZ); Algae (A); Other vertebrates (V)

Values calculated for the species in this study are in bold. (Data of other species from Collar and Wainwright 2006; Bansode et al. 2014 and Sonnefeld et al. 2014)

References: [1] Froese and Pauly (2020); [2] Sonnefeld et al. (2014); [3] Eastman and De Vries (2000); [4] Stevens et al. (2014); [5] Muus et al. (1999); [6] Bowman et al. (2000); [7] Page and Burr (2011); [8] Collette (1999); [9] Eschmeyer and Herald (1999); [10] Dewitt et al. (1990); [11] Pinkerton (2017); [12] Heemstra and Randall (1993); [13] Nahrgang et al. (2014); [14] Matley et al. (2013); [15] Smith-Vaniz (1986); [16] Allen (1985); [17] Randall (1996); [18] Courtenay and Sahlman (1978); [19] Anderson (1990); [20] Bansode et al. (2014); [21] Papaconstantinou and Caragitsou (1989); [22] Donald and Kooyman (1977); [23] Robins and Ray (1986); [24] Kimura et al. (2007); [25] McBride et al. 
Table 4 (continued)

(2010); [26] Morrow (1980); [27] Collette (1986);[28] Whitehead (1988); [29] Lange et al. (2020)

value corresponds to the double functions to crush benthic organisms (e.g. crabs, mussels, and other invertebrates) and to grab nektonic fishes (Yearger et al. 2014).

A combination of medium to low MA values and medium to high SI values is found among suction and ram-suction feeders, respectively. In the centrarchid bluegill (Lepomis macrochirus), a pure suction feeder, the high SI derived from the large buccal cavity and cross-sectional area of the epaxalis, allows feeding on soft, substrateattached or elusive prey such as shrimp, small crabs, and fishes (Sonnefeld et al. 2014).

However, pure suction feeding is rare, in most cases suction is associated to ram activity and enacted by rapid bursts of swimming speed coupled to a powerful suction force (Wainwright and Richard 1995). The suction force (SI value) may adjust according to the prey of interest because feeding on prey suspended in the pelagic zone requires a lower suction force compared to feeding on sessile prey fixed to the substratum. Based on the biomechanics of suction, suction feeding is also supported by the capability to produce force with jaws, resulting in medium MA values (Westneat 2004; Collar and Wainwright 2006).

Polar cod has a medium to high SI value for a planktivore fish and jaw-closing MA values attributable to ram-suction feeding. Similar MA values are indeed found in the ramsuction midwater zooplanktivore wrasses (Labridae) Halichoeres pictus and Clepticus parrae (Wainwright and Richard 1995). Despite having a slightly higher MA value and slightly lower SI value, Antarctic silverfish falls outside the range of suction feeders (following Wainwright and Richard 1995). Whatever the strategy, both the polar species of our study have the typical characteristics of zooplanktivor fishes, such as high visual acuity (i.e. large eye lenses, Jönsson et al. 2014) and the specialized structure for retaining zooplankton (i.e. elongated gill rakers) (Schmitz and Wainwright 2011).

Based on the biomechanical characteristics, Carlig et al. (2018) concluded that particulate feeding was likely the prevalent planktivory foraging mode in the Antarctic silverfish. This foraging strategy, which seems based on ram activity, is also supported by a good vision (Eastman and Lannoo 2011; La Mesa and Eastman 2012) which allows it to select single planktonic prey in the water column (Lazzaro 1987). This is also supported by the dentition of the Antarctic silverfish, with enlarged teeth about midway in length of lower jaw (DeWitt et al. 1990) and moderately protractile jaws (DeWitt and Hopkins 1977) that allows the Antarctic silverfish to grab relatively large agile pelagic prey items such as euphausiids.
The jaw metrics for polar cod and Antarctic silverfish reinforce the difference between those two species. In the polar cod, a short head and short buccal length support the capability for fast movements of the jaws underlying a suction feeding strategy to capture small motile prey (Wainwright and Bellwood 2002), widespread among midwater predators (Motta 1982, 1988). Compared to Antarctic silverfish, the polar cod would more effectively use suction and particulate ram-suction as the main feeding mode (suggested also by Cusa et al. 2019) also allowed by polar cod lens plasticity (Jönsson et al. 2014) to visually detect individual large prey. These ecomorphological traits are reflected in the diet of adult polar cod which consists of large agile prey such as euphausiids, amphipods, and young fishes (Orlova et al. 2009; Christiansen et al. 2012; Renaud et al. 2012; Matley et al. 2013; Hop and Gjøsæter 2013) and gelatinous appendicularians (Nakano et al. 2016).

Based on the gill raker number, length, and breadth, our ecomorphological analysis highlighted also possible secondary feeding strategies for the studied species.

Gill raker morphology plays an important role in the feeding behaviour of planktivorous fishes, and it is often adopted to explain differences in the diets of planktivorous fishes (Gerking 1994; Castillo-Rivera et al. 1996; Tanaka et al. 2006). Gill raker number and morphology are strictly related to the trophic ecology of species and disclose differences in feeding behaviour at the inter- and intra-specific levels. In the polymorphic whitefish (Coreagonus lavaterus), two morphs are known with different feeding habits: the sparsely raked morph (15-30 gill rakers in the first left arch) with shorter, thicker, and less densely packed rakers that feeds on zoobenthos, and the densely raked morph (28-42 gill rakers in the first left arch) whose diet is dominated by zooplankton and other pelagic prey (Amundsen et al. 2004).

Both the Antarctic silverfish and polar cod differ in the number, length, and breadth of gill rakers, indicative of a differentiated adaptation to planktivory. The morphology of gill rakers in the Antarctic silverfish suggests that this species relies on filter feeding as an alternative foraging mode (Carlig et al. 2018). Gill raker morphology of polar cod (numerous, longer, and narrower gill rakers than those of Antarctic silverfish) and its wider filtering surface, allows polar cod to have an even higher efficiency in retaining medium to small prey in the oral cavity than the Antarctic silverfish. Based on the biomechanical characteristics and gill raker morphology, polar cod may be defined as a pump filter feeder (sensu Lazzaro 1987), capable of rhythmic suctions to capture prey items when prey items are small and/or present at high densities. 
Compared to the extremely effective and complex filter apparatus of herrings (Clupeiformes) that are specialized to feed on small-sized zooplankton (Storm et al. 2020), the gill rakers of the polar cod and Antarctic silverfish are less dense, more spaced, and less numerous, supporting filter feeding as a possible alternative but not the main feeding mode of those species.

Overall, based on the ecomorphological characteristics, polar cod and Antarctic silverfish exhibit feeding plasticity. The Antarctic silverfish may prey on a wide size range of zooplankton owing to its large and strong mouth apparatus equipped with enlarged teeth about midway the length of lower jaw (DeWitt et al. 1990), but they may also rely on tow-net filter feeding, engulfing a volume of water by swimming bursts coupled with fully agape mouth, if small planktonic prey such as copepods are available (Carlig et al. 2018).

The polar cod, on the other hand, may be able to alternate particulate suction feeding and pump filter feeding to optimize energy intake in the presence of small prey. This feeding plasticity is supported also by diet studies that show a broad spectrum of pelagic and benthic prey of different size (Orlova et al. 2009; Christiansen et al. 2012; Renaud et al. 2012; Hop and Gjøsæter 2013; Aune et al. 2021). Such a shift in the feeding mode may be ontogenetic but is also affected by prey density and prey size (Lazzaro 1987). Apparently particulate feeding is favoured when prey items are large and/or occur at low densities, whereas filter feeding prevails when prey are small and/or abundant (Gibson and Ezzi 1992).

The morpho-anatomical traits of the midtrophic Antarctic silverfish and polar cod support an opportunistic feeding strategy with a potential to switch from one feeding mode to another according to the prevailing abundance and size of the available prey. Such plasticity in feeding mode is supported by diet analyses that indicate different preys for both species based on area and seasons (Carlig et al. 2019; Cusa et al. 2019; Mueter 2016; Pinkerton 2017). In addition, planktivorous fishes such as Californian anchovy Engraulis mordax (O'Connell 1972), European pilchard Sardina pilchardus (Garrido et al. 2008), and Atlantic herring Clupea harengus (Gibson and Ezzi 1992) commonly switch between particulate and filter-feeding behaviour according to prey availability. This flexibility in feeding modes may counteract adverse changes in zooplankton communities.

The ongoing warming and sea-ice reduction at both poles lead to transformation of plankton communities, from assemblages dominated by large, lipid-rich copepods and euphasiids, to a more diverse community of smaller and less energy-rich zooplankton (Mintenbeck and Torres 2017). A switch in feeding mode may be advantageous for the two midtrophic species under changing environmental conditions, but it does not necessarily translate into a higher resilience of the ecosystems as a whole or guarantee the maintenance of the energy flow. For example, prey that is low in energy, such as gelatinous zooplankton, may expand become abundant, as already described for some areas (see Rogers et al. 2020 for a review). Because the body conditions of fishes are linked to the availability and the quality of prey, changes in prey could lead to nutritional stress for individuals and populations with consequences across the entire food web (Moore and Gulland, 2014; Steiner et al. 2019). Moreover, in light of ocean warming, fish species spread from lower latitudes toward the Polar Regions, and they may outcompete the native polar fishes such as polar cod and Antarctic silverfish (Hunt et al. 2016; Christiansen 2017).

Further research integrating the functional ecology and adaptive capacity of key species in the context of ongoing change represents the necessary successive step to shed light on the food-web dynamics, address the range of potential ecosystems responses, and project the impact of change in these vulnerable polar ecosystems.

Acknowledgements We thank the TUNU-Programme at UiT-The Arctic University of Norway. The authors are very grateful to the colleagues and crew on board the R/V Helmer Hanssen for their kind collaboration. The New Zealand-Australian Antarctic Ecosystems voyage on Tangaroa was jointly funded by Antarctica New Zealand, Australian Antarctic Division, NIWA, and the New Zealand Ministry for Business, Innovation and Employment. We thank also Paul Brickle and two anonymous referees, whose comments greatly improved the manuscript.

Authors contribution EC, DDB, and LG conceived and designed the analysis. EC, LG, JSC, and RLO collected the samples. EC and DDB performed the analysis. EC wrote the manuscript. DDB, LG, JSC, RLO, MV, EP, and SF improved the manuscript with constructive criticisms. JSC and RLO revised the language.

Funding The study was supported by the Italian National Programme for Antarctic Research (PNRA) projects 16_00281 (POLICY) and 2013/AZ1.18 (RAISE), and contributes to the SCAR Scientific Research Program AnT-ERA (Antarctic sThresholds-Ecosystem Resilience and Adaptation).

Data availability All datasets generated for this study are included in the manuscript.

\section{Declarations}

Conflict of interest The authors declare that the research was conducted in the absence of any commercial or financial relationships that could be construed as a potential conflict of interest.

Ethical approval (include appropriate approvals or waivers) All applicable international, national, and/or institutional guidelines for the care and use of animals were followed and all necessary approvals have been obtained. The sampling of Antarctic silverfish was carried out in accordance with permit AMLR14/04/Tangaroa/ZMFR issued by the 
New Zealand government under the Antarctic Marine Living Resources (AMLR) Act 1981. The sampling of polar cod was conducted in compliance with the Government of Greenland and Norwegian authorities-TUNU document ID: C-17-129.

Consent to participate We declare all relevant parties consented to participate in this study.

Consent for publication We declare all relevant parties have consented to the publication of this work.

Open Access This article is licensed under a Creative Commons Attribution 4.0 International License, which permits use, sharing, adaptation, distribution and reproduction in any medium or format, as long as you give appropriate credit to the original author(s) and the source, provide a link to the Creative Commons licence, and indicate if changes were made. The images or other third party material in this article are included in the article's Creative Commons licence, unless indicated otherwise in a credit line to the material. If material is not included in the article's Creative Commons licence and your intended use is not permitted by statutory regulation or exceeds the permitted use, you will need to obtain permission directly from the copyright holder. To view a copy of this licence, visit http://creativecommons.org/licenses/by/4.0/.

\section{References}

Ajiad AM, Oganin IA, Gjøsæter H (2011) Polar cod. Russian-Norwegian Cooperation in Science and Management. Tapir Academic Press, Trondheim, Norway, The Barents Sea Ecosystem, pp 315-328

Allen GR (1985) Snappers of the world. An annotated and illustrated catalogue of lutjanid species known to date. FAO Fisheries Synopsis 125, vol 16, Rome

Amundsen PA, Bøhn T, Våga GH (2004) Gill raker morphology and feeding ecology of two sympatric morphs of European whitefish (Coregonus lavaretus). Ann Zool Fenn 41:291-300

Anderson ME (1990) Zoarcidae. In: Gon O and Heemstra PC (eds) Fishes of the Southern Ocean. JLB Smith Institute of Ichthyology, Grahamstown. pp 256-276

Aune M, Raskhozheva E, Andrade $\mathrm{H}$ et al (2021) Distribution and ecology of polar cod (Boreogadus saida) in the eastern Barents Sea: a review of historical literature. Mar Environ Res 166:105262. https://doi.org/10.1016/j.marenvres.2021.105262

Bakun A (2006) Wasp-waist populations and marine ecosystem dynamics: navigating the "predator pit" topographies. Progr Oceanogr 68:271-288. https://doi.org/10.1016/j.pocean.2006.02.004

Bansode MA, Eastman JT, Aronson RB (2014) Feeding biomechanics of five demersal Antarctic fishes. Polar Biol 37:1835-1848. https://doi.org/10.1007/s00300-014-1565-z

Barnett A, Bellwood DR, Hoey AS (2006) Trophic ecomorphology of cardinalfish. Mar Ecol Prog Ser 322:249-257. https://doi.org/ 10.3354/meps322249

Beaugrand G, Brander KM, Lindley JA, Souissi S, Reid PC (2003) Plankton effect on cod recruitment in the North Sea. Nature 426:661-664. https://doi.org/10.1038/nature02164

Benoit D, Simard Y, Gagné J, Geoffroy M, Fortier L (2010) From polar night to midnight sun: photoperiod, seal predation, and the diel vertical migrations of polar cod (Boreogadus saida) under landfast ice in the Arctic Ocean. Polar Biol 33:1505-1520. https:// doi.org/10.1007/s00300-010-0840-x

Bowman RE, Stillwell CE, Michaels WL, Grosslein MD (2000) Food of Northwest Atlantic fishes and two common species of squid. NOAA Technical Memorandum NMFS-NE 155:1-137
Bradstreet MSW, Finley KJ, Sekerak AD, Griffiths WD, Evans CR, Fabijan MF, Stallard HE (1986) Aspects of the biology of Arctic cod Boreogadus saida and its importance in Arctic marine food chains. Can Tech Rep Fish Aquat Sci 1491:1-193

Brodeur RD, Mills CE, Overland JE, Walters GE, Schumacher JD (1999) Evidence for a substantial increase in gelatinous zooplankton in the Bering Sea, with possible links to climate change. Fish Oceanogr 8:296-306. https://doi.org/10.1046/j.1365-2419. 1999.00115.x

Carlig E, Di Blasi D, Ghigliotti L, Pisano E, Faimali M, O'Driscoll R, Parker S, Vacchi M (2018) Diversification of feeding structures in three adult Antarctic nototheniid fish. Polar Biol 41:17071715. https://doi.org/10.1007/s00300-018-2310-9

Carlig E, Di Blasi D, Ghigliotti L, Pisano E, Koubbi P, Vacchi M (2019) Diversified feeding strategies of Pleuragramma antarctica (Nototheniidae) in the Southern Ocean. Polar Biol 42:20452054. https://doi.org/10.1007/s00300-019-02579-0

Carroll AM, Wainwright PC, Huskey SH, Collar DC, Turingan RG (2004) Morphology predicts suction feeding performance in centrarchid fishes. J Exp Biol 207:3873-3881. https://doi.org/ 10.1242/jeb.0122

Castillo-Rivera M, Kobelkowsky A, Zamayoa V (1996) Food resource partitioning and trophic morphology of Brevoortia gunteri and $\mathrm{B}$ patronus. J Fish Biol 49(6):1102-1111

Christiansen JS (2012) The TUNU-Programme: Euro-Arctic Marine Fishes-Diversity and Adaptation. In: di Prisco G, Verde C (eds) Adaptation and Evolution in Marine Environments, Vol 1. From Pole to Pole. Springer, Berlin, Heidelberg. https://doi.org/10. 1007/978-3-642-27352-0_3

Christiansen JS (2017) No future for Euro-Arctic ocean fishes?. Mar Eco pro Ser 575:217-227. https://doi.org/10.3354/meps12192

Christiansen JS, Hop H, Nilssen EM, Joensen J (2012) Trophic ecology of sympatric Arctic gadoids, Arctogadus glacialis (Peters, 1872) and Boreogadus saida (Lepechin, 1774), in NE Greenland. Polar Biol 35:1247-1257. https://doi.org/10.1007/s00300-012-1170-y

Cohen DM, Inada T, Iwamoto T, Scialabba N (1990) Gadiform fishes of the world (Order Gadiformes). An annotated and illustrated catalogue of cods, hakes, grenadiers and other gadiform fishes known to date. FAO Fisheries Synopsis 125, vol 10, Rome, pp $1-442$

Collar DC, Wainwright PC (2006) Discordance between morphological and mechanical diversity in the feeding mechanism of centrarchid fishes. Evolution 60:2575-2584. https://doi.org/10.1111/j. 0014-3820.2006.tb01891.x

Collette BB (1986) Scombridae. In: Whitehead PJP, Bauchot M-L, Hureau J-C, Nielsen J, Tortonese E (eds) Fishes of the Northeastern Atlantic and the Mediterranea, vol 2. UNESCO, Paris, pp 981-997

Collette BB (1999) Coryphaenidae. Dolphinfishes, "dolphins". In: Carpenter KE and V.H. Niem VH (eds) FAO species identification guide for fishery purposes. The living marine resources of the Western Central Pacific. Bony fishes part 2 (Mugilidae to Carangidae), vol 4. Rome, pp 2656-2658

Courtenay WR, Sahlman HF (1978) Pomadasyidae. In: Fischer W (ed) FAO species identification sheets for fishery purposes. Western Central Atlantic (Fishing Area 31), vol 4, Rome

Crawford RE, Vagle S, Carmack EC (2012) Water mass and bathymetric characteristics of polar cod habitat along the continental shelf and slope of the Beaufort and Chuckchi seas. Polar Biol 35:179-190. https://doi.org/10.1007/s00300-011-1051-9

Cusa M, Berge J, Varpe $\varnothing ~(2019)$ Seasonal shifts in feeding patterns: individual and population realized specialization in a high Arctic fish. Ecol Evol 9:11112-11121. https://doi.org/10.1002/ece3. 5615

De Vries AL, Eastman JT (1978) Lipid sacs as a buoyancy adaptation in Antarctic fish. Nature 271:352-353 
DeWitt HH, Hopkins TL (1977) Aspects of the diet of the Antarctic silverfish, Pleuragramma antarcticum. In: Llano GA (ed) Adaptations within Antarctic ecosystems. Proc 3rd SCAR Symp Antarct Biol. Smithsonian Institution, Washington, pp 557-567

DeWitt HH, Heemstra PC, Gon O (1990) Nototheniidae. Fishes of the Southern Ocean. JLB Smith Institute of Ichthyology, Grahamstown, pp 279-331

Donald DB, Kooyman AH (1977) Food, feeding habits, and growth of goldeye, Hiodon alosoides (Rafinesque), in waters of the PeaceAthabasca Delta. Can J Zool 55(6):1038-1047

Duhamel G, Hulley P-A, Causse R et al (2014) Biogeographic patterns of fish. In: De Broyer C, Koubbi P, Griffiths HJ, Raymond B et al (eds) Biogeographic Atlas of the Southern Ocean. Scientific Committee on Antarctic Research, Cambridge, pp 328-362

Eastman JT (1988) Lipid storage systems and the biology of two neutrally buoyant Antarctic notothenioid fishes. Comp Bioch Physiol B 90(3):529-537

Eastman JT, De Vries AL (2000) Aspects of the body size and gonadal histology in the Antarctic toothfish, Dissostichus mawsoni, from McMurdo Sound, Antarctica. Polar Biol 23:189-195

Eastman JT, Lannoo MJ (2011) Divergence of brain and retinal anatomy and histology in pelagic Antarctic notothenioid fishes of the sister taxa Dissostichus and Pleuragramma. J Morphol 272(4):419-441. https://doi.org/10.1002/jmor.10926

Eschmeyer WN, Herald ES (1999) A field guide to Pacific coast fishes: North America. Houghton Mifflin Harcourt

Falk-Petersen IB, Frivoll V, Gulliksen B, Haug T (1986) Occurrence and size/age relations of polar cod, Boreogadus saida (Lepechin), in Spitsbergen coastal waters. Sarsia 71:235-245. https://doi.org/ 10.1080/00364827.1986.10419693

Fischer W, Hureau JC (1985) FAO species identification sheets for fishery purposes: Southern Ocean, vol 1, 2. Rome

Froese R, Pauly D (2020) FishBase. World Wide Web electronic publication. www.fishbase.org. Accessed $2 \mathrm{Feb} 2021$

Fuiman LA, Davis RW, Williams TM (2002) Behavior of midwater fishes under Antarctic ice: observations by a predator. Mar Biol 140:815-822. https://doi.org/10.1007/s00227-001-0752-y

Garrido S, Ben-Hamadou R, Oliveira PB, Cunha ME, Chícharo MA, van der Lingen CD (2008) Diet and feeding intensity of sardine Sardina pilchardus: correlation with satellite-derived chlorophyll data. Mar Ecol Prog Ser 354:245-256. https://doi.org/10.3354/ meps07201

Geoffroy M, Majewski A, LeBlanc M et al (2016) Vertical segregation of age- 0 and age-1+ polar cod (Boreogadus saida) over the annual cycle in the Canadian Beaufort Sea. Polar Biol 39:10231037. https://doi.org/10.1007/s00300-015-1811-z

Gerasimchuk VV (1986) Characteristics of Antarctic silverfish, Pleuragramma antarcticum (Nototheniidae), from Olaf-Pruds Bay (Commonwealth Sea, eastern Antarctica) with notes on the identification of the species. J Ichthyol 26:10-17

Gerking SD (1994) Feeding Ecology of Fish. San Diego. Academic Press, CA

Ghigliotti L, Ferrando S, Carlig E, Di Blasi D, Gallus L, Pisano E, Hanchet S, Vacchi M (2017) Reproductive features of the Antarctic silverfish (Pleuragramma antarctica) from the Western Ross Sea. Polar Biol 40:199-211. https://doi.org/10.1007/ s00300-016-1945-7

Gibson RN, Ezzi IA (1992) The relative profitability of particulateand filter-feeding in the herring Clupea Harengus L. J Fish Biol 40(4):577-590

Gidmark NJ, Pos K, Matheson B, Ponce E, Westneat MW (2019) Functional morphology and biomechanics of feeding in fishes. In: Bels V, Whishaw I (eds) Feeding in Vertebrates. Fascinating Life Sciences. Springer, Cham. https://doi.org/10.1007/ 978-3-030-13739-7_9
Gillispie JG, Smith RL, Barbour E, Barber WE (1997) Distribution, abundance, and growth of Arctic cod in the northeastern Chukchi Sea. In: Fish ecology in Arctic North America. American Fisheries Society Symposium, vol 19, pp 81-89

Giraldo C, Cherel Y, Vallet C, Mayzaud P, Tavernier E, Moteki M, Hosie G, Koubbi P (2011) Ontogenic changes in the feeding ecology of the early life stages of the Antarctic silverfish (Pleuragramma antarcticum) documented by stable isotopes and diet analysis in the Dumont d'Urville Sea (East Antarctica). Polar Sci 5:252-263. https://doi.org/10.1016/j.polar.2011.04.004

Gray BP, Norcross BL, Blanchard AL, Beaudreau AH, Seitz AC (2016) Variability in the summer diets of juvenile polar cod (Boreogadus saida) in the northeastern Chukchi and western Beaufort Seas. Polar Biol 39:1069-1080. https://doi.org/10.1007/ s00300-015-1796-7

Heemstra PC, Randall JE (1993) Groupers of the world. (Family Serranidae, Subfamily Epinephelinae). An annotated and illustrated catalogue of grouper, rockcod, hind, coral grouper and lyretail species known to date. FAO Fisheries Synopsis 125, vol 16. Rome, p 382

Henson SA, Beaulieu C, Lampitt R (2016) Observing climate change trends in ocean biogeochemistry: when and where. Glob Change Biol 22:1561-1571. https://doi.org/10.1111/gcb.13152

Hop H, Gjøsæter H (2013) Polar cod (Boreogadus saida) and capelin (Mallotus villosus) as key species in marine food webs of the Arctic and the Barents Sea. Mar Biol Res 9:878-894. https://doi. org/10.1080/17451000.2013.775458

Hubold G, Tomo AP (1989) Age and growth of Antarctic silverfish Pleuragramma antarcticum Boulenger, 1902, from the southern Weddell Sea and Antarctic Peninsula. Polar Biol 9:205212. https://doi.org/10.1007/BF00263768

Hunt GL Jr, Drinkwater KF, Arrigo K et al (2016) Advection in polar and sub-polar environments: Impacts on high latitude marine ecosystems. Progr Oceanogr 149:40-81. https://doi.org/10. 1016/j.pocean.2016.10.004

Jönsson M, Varpe Ø, Kozłowski T, Berge J, Kröger RH (2014) Differences in lens optical plasticity in two gadoid fishes meeting in the Arctic. J Comp Physiol A 200:949-957. https://doi.org/ 10.1007/s00359-014-0941-z

Kellermann A (1987) Food and feeding ecology of postlarval and juvenile Pleuragramma antarcticum (Pisces; Notothenioidei) in the seasonal pack ice zone off Antarctic Peninsula. Polar Biol 7:307-315. https://doi.org/10.1007/BF00443949

Kessel ST, Hussey NE, Crawford RE, Yurkowski DJ, Webber DM, Dick TA, Fisk AT (2017) First documented large-scale horizontal movements of individual Arctic cod (Boreogadus saida). Can J Fish Acquatic Sci 74(3):292-296. https://doi.org/ 10.1139/cjfas-2016-0196

Kimura S, Golani D, Iwatsuki Y, Tabuchi M, Yoshino T (2007) Redescriptions of the Indo-Pacific atherinid fishes Atherinomorus forskalii, Atherinomorus lacunosus, and Atherinomorus pinguis. Ichthyol Res 54(2):145-159. https://doi.org/10.1007/ s10228-006-0386-7

Klingenberg CP, Ekau W (1996) A combined morphometric and phylogenetic analysis of an ecomorphological trend: pelagization in Antarctic fishes (Perciformes: Nototheniidae). Biol J Linnean Soc 59:143-177. https://doi.org/10.1111/j.1095-8312. 1996.tb01459.x

Knox GA (1994) The biology of the Southern Ocean. Cambridge University Press, Cambrige

Koubbi P, O'Brien C, Loots C et al (2011) Spatial distribution and inter-annual variations in the size frequency distribution and abundances of Pleuragramma antarcticum larvae in the Dumont d'Urville Sea from 2004 to 2010. Polar Sci 5:225238. https://doi.org/10.1016/j.polar.2011.02.003 
Koubbi P, Grant S, Ramm D, Vacchi M, Ghigliotti L, Pisano E (2017) Conservation and Management of Antarctic Silverfish Pleuragramma antarctica Populations and Habitats. In: Vacchi M, Pisano E, Ghigliotti L (eds) The Antarctic Silverfish: a Keystone Species in a Changing Ecosystem. Advances in Polar Ecology, vol 3. Springer, Cham. https://doi.orghttps://doi.org/ 10.1007/978-3-319-55893-6_13

La Mesa M, Eastman JT (2012) Antarctic silverfish: life strategies of a key species in the high-Antarctic ecosystem. Fish Fish 13:241-266. https://doi.org/10.1111/j.1467-2979.2011. 00427.x

La Mesa M, Catalano B, Russo A, Greco S, Vacchi M, Azzali M (2010) Influence of environmental conditions on spatial distribution and abundance of early life stages of Antarctic silverfish, Pleuragramma antarcticum (Nototheniidae), in the Ross Sea. Antarct Sci 22:243-254. https://doi.org/10.1017/S0954102009990721

Lancraft TM, Reisenbichler KR, Robinson BH, Hopkins TL, Torres JJ (2004) A krill-dominated micronekton and macrozooplankton community in Croker Passage, Antarctica with an estimate of fish predation. Deep Sea Res II 51:2247-2260. https://doi.org/ 10.1016/j.dsr2.2004.07.004

Lange ID, Perry CT, Morgan KM, Roche R, Benkwitt CE, Graham NA (2020) Site-level variation in parrotfish grazing and bioerosion as a function of species-specific feeding metrics. Diversity 12(10):379. https://doi.org/10.3390/d12100379

Lazzaro XA (1987) A review of planktivorous fishes: their evolution, feeding behaviours, selectivities, and impacts. Hydrobiologia 146:97-167. https://doi.org/10.1007/BF00008764

Lehodey P, Murtugudde R, Senina I (2010) Bridging the gap from ocean models to population dynamics of large marine predators: a model of mid-trophic functional groups. Progr Oceanogr 84:69-84. https://doi.org/10.1016/j.pocean.2009.09.008

Liem KF (1980) Acquisition of energy by teleosts: adaptive mechanisms and evolutionary patterns. In: Ali MA (ed) Environmental physiology of fishes. Plenum Press, NewYork, pp 299-334

Luiz OJ, Crook DA, Kennard MJ, Olden JD, Saunders TM, Douglas MM, Wedd D, King AJ (2019) Does a bigger mouth make you fatter? Linking intraspecific gape variability to body condition of a tropical predatory fish. Oecologia 191:579-585. https://doi. org/10.1007/s00442-019-04522-w

Magnuson JJ, Heitz JG (1971) Gill raker apparatus and food selectivity among mackerels, tunas, and dolphins. Fish Bull 69:361-370

Matley JK, Fisk AT, Dick TA (2013) The foraging ecology of Arctic cod (Boreogadus saida) during open water (July-August) in Allen Bay, Arctic Canada. Mar Biol 60:2993-3004. https://doi. org/10.1007/s00227-013-2289-2

McBride RS, Rocha CR, Ruiz-Carus R, Bowen BW (2010) A new species of ladyfish, of the genus Elops (Elopiformes: Elopidae), from the western Atlantic Ocean. Zootaxa 2346:29-41

McGill BJ, Enquist BJ, Weiher E, Westoby M (2006) Rebuilding community ecology from functional traits. Trends Ecol Evol 21:178185. https://doi.org/10.1016/j.tree.2006.02.002

Mecklenburg CW, Lynghamma A, Johannesen E et al (2018) Marine fishes of the Arctic Region. Akureyri: Conservation of arctic flora and fauna. https://caff.is/monitoring-series/ 451-marine-fishes-of-the-arctic-region-vol-1.

Mintenbeck K, Torres JJ (2017) Impact of climate change on the Antarctic silverfish and its consequences for the Antarctic ecosystem. In: Vacchi M, Pisano E, Ghigliotti L (eds) The Antarctic silverfish:a keystone species in a changing ecosystem. Springer Series Advances in Polar Ecology, pp 253-286. https://doi.org/ 10.1007/978-3-319-55893-6_12

Mintenbeck K, Barrera-Oro ER, Brey T, Jacob U, Knust R, Mark FC, Moreira E, Strobel A, Arntz WE (2012) Impact of climate change on fishes in complex antarctic ecosystems. Adv Ecol Res 46:351426. https://doi.org/10.1016/B978-0-12-396992-7.00006-X
Moore S, Gulland F (2014) Linking marine mammal and ocean health in the 'new normal' arctic. Ocean Coast Manag 102:55-57. https://doi.org/10.1016/j.ocecoaman.2014.08.011

Morrow JE (1980) The freshwater fishes of Alaska. University of BC, Animal Resources Ecology Library, p 248

Motta PJ (1982) Functional morphology of the head of the inertial suction feeding butterflyfish, Chaetodon miliaris (Perciformes, Chaetodontidae). J Morphol 74:283-312. https://doi.org/10. 1002/jmor.1051740305

Motta PJ (1988) Functional morphology of the feeding apparatus of ten species of Pacific butterflyfishes (Perciformes, Chaetodontidae): an ecomorphological approach. Env Biol Fish 22:39-67. https:// doi.org/10.1007/BF00000543

Motta PJ, Norton SF, Luczkovich JJ (1995) Perspectives on the ecomorphology of bony fishes. Env Biol Fish 44:11-20. https://doi. org/10.1007/BF00005904

Mueter FJ, Nahrgang J, John Nelson R, Berge J (2016) The ecology of gadid fishes in the circumpolar Arctic with a special emphasis on the polar cod (Boreogadus saida). Polar Biol 39:961-967. https:// doi.org/10.1007/s00300-016-1965-3

Murphy EJ, Cavanagh RD, Drinkwater KF, Grant SM, Heymans JJ, Hofmann EE, Hunt GL, Johnston NM (2016) Understanding the structure and functioning of polar pelagic ecosystems to predict the impacts of change. Proc R Soc B 283:2016-1646. https://doi. org/10.1098/rspb.2016.1646

Muus BJ, Nielsen JG, Dahlstrøm P, Nyström BO (1999) Sea fish. Hedehusene, Narayana Press, Odder, Scandinavian Fishing Year Book

Nahrgang J, Varpe Ø, Korshunova E, Murzina S, Hallanger IG, Vieweg I, Berge J (2014) Gender specific reproductive strategies of an Arctic key species (Boreogadus saida) and implications of climate change. PLoS one 9(5):e98452. https://doi.org/10.1371/ journal.pone.0098452

Nahrgang J, Storhaug E, Murzina SA, Delmas O, Nemova NN, Berge J (2016) Aspects of reproductive biology of wild-caught polar cod (Boreogadus saida) from Svalbard waters. Polar Biol 39(6):1155-1164. https://doi.org/10.1007/s00300-016-1965-3

Nakano T, Matsuno K, Nishizawa B, Iwahara Y, Mitani Y, Yamamoto J, Sakurai Y, Watanuki Y (2016) Diets and body condition of polar cod (Boreogadus saida) in the northern Bering Sea and Chukchi Sea. Polar Biol 39:1081-1086. https://doi.org/10.1007/ s00300-015-1769-x

Norton SF, Brainerd EL (1993) Convergence in the feeding mechanics of ecomorphologically similar species in the Centrarchidae and Cichlidae. J Exp Biol 176(1):11-29

O'Driscoll RL, Ladroit Y, Parker SJ, Vacchi M, Canese S, Ghigliotti L, Dunford AJ, Mormede S (2018) Acoustic deployments reveal Antarctic silverfish under ice in the Ross Sea. Antarct Sci 30:345-353. https://doi.org/10.1017/S0954102018000366

O'Connell CP (1972) The interrelation of biting and filtering in the feeding activity of the northern anchovy (Engraulis mordax). $\mathrm{J}$ Fish Res Board Can 29(3):285-293

O'Driscoll R, Double M (2015) Voyage Report TAN1502: New Zealand-Australia Antarctic Ecosystems Voyage. NIWA Client Report WLG2015-21

Orlova EL, Dolgov AV, Rudneva GB, Oganin IA, Konstantinova LL (2009) Trophic relations of capelin Mallotus villosus and polar cod Boreogadus saida in the Barents Sea as a factor of impact on the ecosystem. Deep Sea Res Pt II 56:2054-2067. https://doi. org/10.1016/j.dsr2.2008.11.016

Page LM, Burr BM (2011) Peterson's field guide to freshwater fishes. Houghton Mifflin Company, New York

Papaconstantinou C, Caragitsou E (1989) Feeding interaction between two sympatric species Pagrus pagrus and Phycis phycis around Kastellorizo Island (Dodecanese, Greece). Fish Res 7(4):329-342 
Pinkerton MH (2017) Diet and trophic ecology of adult Antarctic silverfish (Pleuragramma antarctica). In: Vacchi M, Pisano E, Ghigliotti L (eds) The Antarctic silverfish: a keystone species in a changing ecosystem. Springer Series Advances in Polar Ecology, pp 93-111. https://doi.org/10.1007/978-3-319-55893-6_5

Plötz J, Bornemann H, Knust R, Schröder A, Bester M (2001) Foraging behaviour of Weddell seals, and its ecological implications. Polar Biol 24:901-909. https://doi.org/10.1007/978-3-642-59419-9_20

Ponomarenko VP (1968) Some data on the distribution and migrations of polar cod in the seas of the Soviet Arctic. Rapp P-V Reun Cons Perm Int Explor Mer 158:131-135

R Development Core Team (2015). R: a language and environment for statistical computing. R Foundation for statistical computing. Vienna, Austria. www.R-project.org

Randall JE (1996) Caribbean reef fishes, 3rd edn. TFH Publications, Neptune City, p 368

Renaud PE, Berge J, Varpe Ø, Lønne OJ, Nahrgang J, Ottesen C, Hallanger I (2012) Is the poleward expansion by Atlantic cod and haddock threatening native polar cod, Boreogadus saida? Polar Biol 35:401-412. https://doi.org/10.1007/s00300-011-1085-z

Robins CR, Ray GC (1986) A field guide to Atlantic coast fishes of North America. Houghton Mifflin Company, Boston, USA, p 354

Robison BH (2003) What drives the diel vertical migrations of Antarctic midwater fish? J Mar Biol Assoc UK 83:639-642. https:// doi.org/10.1017/S0025315403007586h

Rogers AD, Frinault BAV, Barnes DKA et al (2020) Antarctic futures: an assessment of climate-driven changes in ecosystem structure, function, and service provisioning in the Southern Ocean. Annu Rev Mar Sci 12:7.1-7.34. https://doi.org/10.1146/annur ev-marine-010419-011028

Schmitz L, Wainwright PC (2011) Ecomorphology of the eyes and skull in zooplanktivorous labrid fishes. Coral Reefs 30(2):415428. https://doi.org/10.1007/s00338-010-0714-2

Smith-Vaniz WF (1986) Carangidae. In: Whitehead PJP, Bauchot M-L, Hureau J-C, Nielsen J, Tortonese E (eds) Fishes of the Northeastern Atlantic and the Mediterranean, vol 2. UNESCO, Paris, pp 815-844

Sonnefeld MJ, Turingan RG, Sloan TJ (2014) Functional morphological drivers of feeding mode in marine teleost fishes. Adv Zool Bot 2:6-14. https://doi.org/10.13189/azb.2014.020102

Steiner NS, Cheung WWL, Cisneros-Montemayor AM et al (2019) Impacts of the changing ocean-sea ice system on the key forage fish arctic cod (Boreogadus saida) and subsistence fisheries in the western canadian arctic-evaluating linked climate, ecosystem and economic (CEE) models. Front Mar Sci 6:179. https://doi. org/10.3389/fmars.2019.00179

Stevens DW, Dunn MR, Pinkerton MH, Forman JS (2014) Diet of Antarctic toothfish (Dissostichus mawsoni) from the continental slope and oceanic features of the Ross Sea region. Antarctica Antarct Sci 26(5):502. https://doi.org/10.1017/S095410201 300093X

Storm TJ, Nolan KE, Roberts EM, Sanderson SL (2020) Oropharyngeal morphology related to filtration mechanisms in suspensionfeeding American shad (Clupeidae). J Exp Zool A Ecol and Integr Physiol 333(7):493-510. https://doi.org/10.1002/jez.2363

Sutton CP, Horn PL (2011) A preliminary assessment of age and growth of Antarctic silverfish. CCAMLR Science 18:75-86

Tanaka H, Aoki I, Ohshimo S (2006) Feeding habits and gill raker morphology of three planktivorous pelagic fish species off the coast of northern and western Kyushu in summer. J Fish Biol 68:10411061. https://doi.org/10.1111/j.0022-1112.2006.00988.x

Tavernier E, Giraldo C (2017) Trophic ecology of early developmental stages of Antarctic silverfish. In: Vacchi M, Pisano E, Ghigliotti
L (eds) The Antarctic silverfish: a keystone species in a changing ecosystem. Springer Series Advances in Polar Ecology, pp 113-130. https://doi.org/10.1007/978-3-319-55893-6_6

Vacchi M, DeVries AL, Evans CW, Bottaro M, Ghigliotti L, Cutroneo L, Pisano E (2012a) A nursery area for the Antarctic silverfish Pleuragramma antarcticum at Terra Nova Bay (Ross Sea): first estimate of distribution and abundance of eggs and larvae under the seasonal sea-ice. Polar Biol 35:1573-1585. https://doi.org/ 10.1007/s00300-012-1199-y

Vacchi M, Koubbi P, Ghigliotti L, Pisano E (2012b) Sea-Ice Interactions with Polar Fish: Focus on the Antarctic Silverfish Life History. In: di Prisco G, Verde C (eds) Adaptation and Evolution in Marine Environments. Vol 1, From Pole to Pole. Springer, Berlin, Heidelberg. https://doi.org/10.1007/978-3-642-27352-0_4

Villéger S, Brosse S, Mouchet M, Mouillot D, Vanni MJ (2017) Functional ecology of fish: current approaches and future challenges. Aquat Sci 79:783-801. https://doi.org/10.1007/ s00027-017-0546-z

Voskoboinikova O, Detrich HW III, Albertson C et al (2017) Evolution reshaped life for the water column: the skeleton of the Antarctic silverfish Pleuragramma antarctica Boulenger, 1902. In: Vacchi M, Pisano E, Ghigliotti L (eds) The Antarctic silverfish. A keystone species in a changing ecosystem. Springer Series Advances in Polar Ecology. https://doi.org/10.1007/978-3-319-55893-6_1

Wainwright PC (1988) Morphology and ecology: functional basis of feeding constraints in Caribbean labrid fishes. Ecology 69:635645. https://doi.org/10.2307/1941012

Wainwright PC, Bellwood DR (2002) Ecomorphology of feeding in coral reef fishes. In: Sale PF (ed) Coral reef fishes: dynamics and diversity in a complex ecosystem. Academic Press, San Diego, pp 33-55

Wainwright PC, Richard BA (1995) Predicting patterns of prey use from morphology of fishes. Environ Biol Fish 44:97-113. https:// doi.org/10.1007/BF00005909

Walkusz W, Majewski A, Reist JD (2013) Distribution and diet of the bottom dwelling Arctic cod in the Canadian Beaufort Sea. J Mar Syst 127:65-75. https://doi.org/10.1016/j.jmarsys.2012.04.004

Westneat MW (2004) Evolution of levers and linkages in the feeding mechanisms of fishes. Integr Comp Biol 44:378-389. https://doi. org/10.1093/icb/44.5.378

Westneat MW (2006) Skull biomechanics and suction feeding in fishes. In: Shadwick RE, Lauder GV (eds) Fish biomechanics. Elsevier Academic Press, San Diego, pp 29-75

Whitehead PJP, Nelson GJ, Wongratana T (1988) Clupeoid fishes of the world (Suborder Clupeoidei). An annotated and illustrated catalogue of the herrings, sardines, pilchards, sprats, anchovies and wolf-herrings. Part II - Engraulididae. FAO Fisheries Synopsis, Rome 7:305-579

Wöhrmann APA, Hagen W, Kunzmann A (1997) Adaptations of the Antarctic silverfish Pleuragramma antarcticum (Pisces: Nototheniidae) to pelagic life in high-Antarctic waters. Mar Ecol Progr Ser 151:205-218. https://doi.org/10.3354/meps151205

Yeager LA, Layman CA, Hammerschlag-Peyer CM (2014) Diet variation of a generalist fish predator, grey snapper Lutjanus griseus, across an estuarine gradient: trade-offs of quantity for quality? J Fish Biol 85(2):264-277. https://doi.org/10.1111/jfb.12416

Publisher's Note Springer Nature remains neutral with regard to jurisdictional claims in published maps and institutional affiliations. 